\title{
Rursus
}

Poiétique, réception et réécriture des textes antiques

$6 \mid 2011$

Relire, récrire, prolonger. Adaptations gréco-latines

\section{Le chœur dans les luttes d'Aristophane. Rôle et évolution des interventions du chœur dans les scènes d'agôn chez Aristophane}

Résumé de mémoire de littérature grecque (M2) sous la direction de Mlle Jacqueline Assaël (2009-2010)

The Chorus and Aristophanes' fights. Role and evolution of the Chorus in the agonistic scenes

\section{Claire Giaume}

\section{OpenEdition}

Journals

Édition électronique

URL : http://journals.openedition.org/rursus/515

DOI : 10.4000/rursus.515

ISSN : 1951-669X

Éditeur

Université Nice-Sophia Antipolis

Référence électronique

Claire Giaume, "Le chœur dans les luttes d'Aristophane. Rôle et évolution des interventions du chœur dans les scènes d'agôn chez Aristophane », Rursus [En ligne], 6 | 2011, mis en ligne le 11 février 2011, consulté le 01 mai 2019. URL : http://journals.openedition.org/rursus/515; DOI : 10.4000/rursus.515

Ce document a été généré automatiquement le 1 mai 2019.

Rursus 


\section{Le chœur dans les luttes} d'Aristophane. Rôle et évolution des interventions du chœur dans les scènes d'agôn chez Aristophane

Résumé de mémoire de littérature grecque (M2) sous la direction de Mlle Jacqueline Assaël (2009-2010)

The Chorus and Aristophanes' fights. Role and evolution of the Chorus in the agonistic scenes

\section{Claire Giaume}

\section{Résumé}

1 L'Ancienne Comédie est un genre théâtral très particulier composés d'éléments qui lui sont propres et qui restent singuliers. Le chœur et l'agôn, présents tous les deux dans la genèse du théâtre, font partie des éléments constitutifs de l'Ancienne Comédie. Au cœur de la tradition grecque depuis la période mythique ils sont des piliers de l'avènement théâtral qui eut pour berceau l'Athènes $d u V^{\circ}$ siècle av. J.-C. Inhérents à l'esprit compétitif grec, ils ont trouvé dans l'Ancienne Comédie un cadre adéquat à leur fonction traditionnelle.

Les auteurs comiques, et parmi eux Aristophane, le seul dramaturge de l'époque dont les œuvres ont résisté au temps, avaient à leur disposition les outils indispensables pour mener leurs luttes. En effet, l'Ancienne Comédie se démarque par son caractère politique. Sur la scène se jouaient les affaires de la cité et les dramaturges usaient de toute leur imagination pour créer une intrigue dans laquelle s'opposaient les personnages au sujet d'une thèse choisie judicieusement. L'agôn, qui fait partie des différentes parties qui composent l'Ancienne Comédie, commence juste après la parodos, l'entrée du chœur sur la scène, et se termine juste avant la parabase: il représente le champ de bataille des 
comédies. Le chœur, porte-parole du poète et représentant sur scène du peuple athénien, est un constituant primordial des comédies et détenait un rôle important dans les scènes de bataille. Etudier le rôle et l'évolution des interventions du chœur dans les scènes d'agôn chez Aristophane permet découvrir le rôle qu'il détenait dans les combats que menait le poète. Il semble en effet intéressant d'examiner en quoi le chœur contribue au comique dans les débats qui animent les pièces, tout en révélant les tourments qui agitaient Athènes.

3 L'étude rappelle tout d'abord la place de l'agôn et du chœur dans la tradition grecque et leur contribution à l'avènement théâtral, puis dans le théâtre d'Aristophane. Ensuite, elle développe leur rôle et leur structure dans des pièces révélatrices. Enfin, elle analyse leur évolution, corrélative aux bouleversements que traversait alors Athènes.

4 Le chœur et l'agôn ont une importance considérable dans la culture grecque antique. L' agôn symbolise dans la tradition l'esprit de compétition, de lutte et de volonté de l'emporter sur son adversaire. Dès Homère la littérature regorge d'exemples démontrant l'importance des jeux et de la compétition chez les Grecs. La notion d'agôn définit un trait caractéristique de cette civilisation. Il en est de même pour le chœur, cet ensemble d'individus réunis pour chanter et danser, dont la littérature révèle de nombreux exemples dans les rituels grecs et l'expression religieuse.

5 L'Ancienne comédie a de particulier qu'elle est centrée sur Athènes, les Athéniens et les problèmes de la Cité. Elle est ancrée dans l'actualité et la réalité quotidienne, mettant en scène des personnages importants de l'époque et offrant un panel des diverses catégories sociales. Chaque pièce pose une thèse que l'auteur soutient dans le cadre de son intrigue. Ses comédies se dévoilent alors comme combattantes des traditions et de l'Ancienne Athènes face à l'esprit nouveau qui pointe son nez dans les esprits. La guerre du Péloponnèse tiraille en effet les Athéniens: la vieille génération continue à prôner le respect des traditions pendant que la nouvelle est fiévreuse de faire table rase du passé. Les comédies témoignent de ces affrontements.

6 La structure même des pièces s'articule autour des combats : toute la première partie, qui s'étend jusqu'à la parabase, est une lutte, un agôn, qui divise les personnages mis en scène. Intervenant peu après l'entrée du chœur, ces scènes agonistiques mettent en évidence dans une lutte verbale les deux thèses qui s'affrontent dans la comédie. Dans les Acharniens, par exemple, Aristophane lutte pour la paix : il met en scène dans l'agôn le héros Dicéopolis se démenant pour convaincre le chœur des bienfaits de la paix et de l'absurdité de la guerre. Le choix du chœur est percutant: il est composé de vieux charbonniers d'Acharnes, un des premiers dèmes de l'Attique à avoir été attaqué par les Spartiates, connaissant d'autant mieux la terrible réalité de la guerre. D'autres thèmes constituent également un point de départ pour des scènes de combat : l'éducation dans les Nuées, les démagogues dans les Cavaliers, la littérature dans les Grenouilles, qui met en scène un agôn entre Euripide et Eschyle. Mais Aristophane ne suit pas dans toutes ses comédies le schéma traditionnel de l'agôn: cette diversité dans la composition n'est pas insignifiante dans l'évolution de l'Ancienne Comédie.

7 L'agôn est donc essentiel dans le combat que mène la comédie, et représente même une caractéristique primordiale des comédies athéniennes, laissant au chœur une place prépondérante. En effet, le personnage choral prend toujours part pour l'une des thèses en jeu, tantôt se dressant contre le héros, tantôt du côté du vainqueur. Il est un personnage essentiel dans les combats d'Aristophane : le chœur est au cœur de la lutte. En outre, il contribue au comique des pièces, grâce à sa fantaisie, sa verve haute en 
couleur, ses répliques bouffonnes, mais aussi au souvenir de la tradition, évoluant sur scène sur des rythmes traditionnels et attendus. Aristophane met le comique et la tradition au service de ses combats et la scène, pendant l'agôn, devient le terrain de confrontations verbales entre l'Ancienne génération et la Nouvelle, un véritable champ de bataille dans lequel le personnage du chœur joue un rôle essentiel.

En outre, les onze pièces d'Aristophane qui sont parvenues jusqu'à nous recouvre une période très tourmentée dans l'histoire d'Athènes et nous permettent de suivre l'évolution politique de l'époque.

Le poète débuta sa carrière quelques années à peine après le début de la guerre du Péloponnèse, qui opposaient les Athéniens aux Spartiates, et ses comédies sont imprégnées de ce contexte belliqueux, qui disparaîtra à la fin de la guerre en laissant place à l'atmosphère noire de la chute d'Athènes.

Dans les dernières pièces, la hargne du poète devient moins virulente, les luttes moins violentes, et la politique va peu à peu laisser la place à d'autres préoccupations. Le contexte influe sans doute beaucoup sur ce changement. La fin de la guerre du Péloponnèse correspond à la chute d'Athènes, à la transformation de la comédie, et à la disparition progressive du chœur. Le théâtre va peu à peu se détacher de l'histoire d'Athènes pour se centrer davantage sur les mœurs. L'agôn perdra son rôle fondamental, et le chœur son utilité et son rôle dramaturgique. Sans combattant, l'Ancienne Comédie n'avait plus de raison d'être.

\section{Abstract}

11 In the fifth century before Christ, Athens became the birthplace of theatre: the Chorus and the Agon were both essential elements of that apparition. They were inherent to the Greek competitive spirit, and found an appropriate setting to grow in old Comedy. Aristophanes, the only comic poet of whom we still keep a few plays, needed them to lead his battles. Meanwhile, the old Comedy was a political theatre, and its plots always involve a struggle opposing two characters defending a different opinion. On the stage the poet exposed the city affairs and expressed his own point of view. The Agon, a part of the comedy pattern, occupied the first half of the play between the Parodos and the Parabasis: it is the battle field of old comedy. The Chorus, the author's spokesman and the representative of the Athenian people on the stage, also had an important role in the fight. The study of the place and the evolution of the Chorus in the Aristophanes' agonistic scenes allows to understand the torments which were troubling the comic poet and all the others Athenians. It seems interesting to examine how the Chorus contributed both to the comic effect and to the fights which drove the plays, revealing the disorders which were perturbing Athens.

At first, this work reminds the place of the Agon and the Chorus in Greek tradition, and their contribution to the emergence of the theatre. Next, it develops their role and their structure in Aristophanes' eleven comedies preserved. At last, it analyses their evolution, relative to the changes, which transformed Athens.

The Chorus and the Agon have a significant importance in the Old Greek tradition.

14 The Agon represents the competitive spirit, the attraction for fight and the will to have the upper hand. From Homer, literature is full of examples showing the importance of games and competition among the Greeks. 

examples of choruses in Greek rituals and religious expression. The Attic Comedy keeps its traditions in memory by the presence of the collective character of the Chorus and the agonistic scenes. anchored in current affairs and everyday reality, showing important personalities of this time and giving a sample of various social groups. Every play presents an idea defended by the author in his plot. Those plays fought against the New Spirit which appeared during this period. The Peloponnesian War tore the Athenians apart: the old generation wanted to perpetuate respectfully the traditions and fought against the new one, which wanted to forget these old traditions and look into the future. The Aristophanic plays show these confrontations and the mentality changes. stretches as far as the Parabasis, are battles, agones, which divide the characters on the stage. Those agonistic scenes take place shortly after the Parodos, the entrance of the Chorus, and show the two theories which are opposed in the play in a verbal contest. For example, in the Acharnians, Aristophanes fights for the peace, and in the agonistic scene, the hero, Dikaipolis, tries to convince the chorus of the benefit of peace and the absurdity of war. The choice of the Chorus is significant: it represents a group of old charcoalburners from Archanes, one of the Attic territories first attacked by Spartans and knowing more than the others the terrible reality of war. Others subjects are a starting point for a struggle: education in the Clouds, the demagogues in the Knights, literature in the Frogs, with a quarrel between Euripides and Aeschylus. Aristophanes did not always follow the typical structure of the Agon, sometimes overstepped it, and that diversity was not insignificant in the evolution of comedy.

The Agon was essential in the battle led by the old comedy, and even represented one of its fundamental characteristics, giving the Chorus a prevailing place. That collective character always took the side of one of the theories defended in the plays, either standing against the hero, or standing up for the winner. The Chorus was an essential character in the fight, and was in the heart of the Agon. Moreover, it also contributed to the comic of the scenes, thanks to its fantasy, its ludicrous vehemence and its warlike replies, following traditional rhythms. Aristophanes used the comic effect to help its fights and the stage, during the Agon, became the field of verbal confrontations in which the old generation opposed the new one, in which the Chorus played an important part. Besides, the eleven plays preserved until now cover a very tormented period in Athens' history and let us follow the political evolution and mentality changes.

21 Aristophanes began his career a few years after the start of the Peloponnesian War, which opposed the Athenians and the Peloponnesian League, led by Sparta, so his comedies were permeated with that context of war, and, at the end of the War, with the dark atmosphere of the fall of Athens.

In the last plays, the aggressiveness of the poet became less virulent, the struggle less violent and politics gradually gave way to other concerns. The context had without doubt an influence on that change: the end of the War tallied with the transformation of Athens, of comedy, and with the progressive disappearance of the Chorus. The Agon itself would 
no longer be necessary for the structure of the plays. Theatre gradually gave up the history of Athens and the fights to emphasize the study of behaviours. In the last comedies, the Agon was less developed and the Chorus lost their essential role. Without any opponents, the Old Comedy had no reason to live on anymore. 